\title{
Facing our whiteness in doing Ubuntu research. Finding spatial justice for the researcher
}

\begin{tabular}{|c|c|}
\hline $\begin{array}{l}\text { Authors: } \\
\text { Julian Müller } \\
\text { Sheila Trahar }{ }^{1}\end{array}$ & \\
\hline $\begin{array}{l}\text { Affiliations: } \\
{ }^{1} \text { Centre for th } \\
\text { of Scholarship } \\
\text { Pretoria, Sout }\end{array}$ & $\begin{array}{l}\text { Advancement } \\
\text { University of } \\
\text { Africa }\end{array}$ \\
\hline $\begin{array}{l}\text { Project leade } \\
\text { Project numb }\end{array}$ & $\begin{array}{l}\text { : J.C. Müller } \\
\text { er: } 02380595\end{array}$ \\
\hline $\begin{array}{l}\text { Description: } \\
\text { Sheila Trahar } \\
\text { the Ubuntu R } \\
\text { directed by Pr } \\
\text { Müller, Centr } \\
\text { Advancement } \\
\text { University of } \\
\text { South Africa }\end{array}$ & $\begin{array}{l}\text { oarticipated in } \\
\text { search Project, } \\
\text { of. Dr Julian } \\
\text { for the } \\
\text { of Scholarship, } \\
\text { retoria, }\end{array}$ \\
\hline $\begin{array}{l}\text { Correspondin } \\
\text { Julian Müller, } \\
\text { Julian.muller }\end{array}$ & $\begin{array}{l}\text { g author: } \\
\text { Dup.ac.za }\end{array}$ \\
\hline $\begin{array}{l}\text { Dates: } \\
\text { Received: } 30 \\
\text { Accepted: } 13 \\
\text { Published: } 01\end{array}$ & $\begin{array}{l}\text { May } 2016 \\
\text { Aug. } 2016 \\
\text { Dec. } 2016\end{array}$ \\
\hline $\begin{array}{l}\text { How to cite tl } \\
\text { Müller, J. \& Tr } \\
\text { 'Facing our w } \\
\text { doing Ubuntu } \\
\text { Finding spatia } \\
\text { researcher', H } \\
\text { Studies/Theol } \\
72(1) \text {, a3510. } \\
\text { org/10.4102/ }\end{array}$ & $\begin{array}{l}\text { is article: } \\
\text { ahar, S., 2016, } \\
\text { iteness in } \\
\text { research. } \\
\text { l justice for the } \\
\text { TS Teologiese } \\
\text { gical Studies } \\
\text { http://dx.doi. } \\
\text { ts.v72i1.3510 }\end{array}$ \\
\hline $\begin{array}{l}\text { Copyright: } \\
\text { (C) 2016. The } \\
\text { Licensee: AOS } \\
\text { is licensed un } \\
\text { Creative Com } \\
\text { Attribution Lic }\end{array}$ & $\begin{array}{l}\text { uthors. } \\
\text { IS. This work } \\
\text { ler the } \\
\text { nons } \\
\text { ense. }\end{array}$ \\
\hline Read online: & \\
\hline 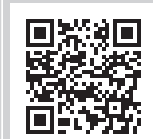 & $\begin{array}{l}\text { Scan this QR } \\
\text { code with your } \\
\text { smart phone or } \\
\text { mobile device } \\
\text { to read online. }\end{array}$ \\
\hline
\end{tabular}

In this article, the two authors, academics from different contexts and both aware of their whiteness, focus on their own vulnerable selves. The aim is to reflect on their specific agency in this project ${ }^{1}$ and to create awareness for subjectivity in research. What are the challenges of two white academics - the one from a first world country with a baggage of colonialism, and the other from South Africa with the apartheid baggage? On the one hand, they are not 'vulnerable' selves but indeed very privileged selves. On the other hand, there is an awareness of the fact that this very privilege puts researchers in a vulnerable situation, especially in doing research on Ubuntu in an African context.

We are two academics from different disciplines. Sheila Trahar conducts research in higher education at the University of Bristol, UK. Julian Müller conducts research in practical theology at the University of Pretoria, South Africa. There are many differences in our stories and yet we find ourselves working together and understanding each other in our recent involvement in a specific research project on Ubuntu at the University of Pretoria. We both have our own stories on how we got involved in this project, and we will share those stories briefly in the following section of this article. In terms of research methodology, we found common ground in our shared commitment to the autoethnographic approach (Müller 2011; Trahar 2011:51-52). This is an approach that travels on the road of autobiographical writing, while observing through the ethnographic lens. Such a journey always displays multiple layers of consciousness, connecting the personal to the cultural. In this research and writing about it, we are using the wide-angle lens - focusing outward on social and cultural aspects, but then reflecting inward and exposing a vulnerable self that is moved by cultural interpretations.

In this article, the focus is on our own vulnerable selves (cf. Butler 2004). Not to create sympathy, because we experience it as a huge privilege to be part of this project, but to create awareness and to reflect on our specific agency in it. What are the challenges of two white academics - the one from a first world country with a baggage of colonialism, and the other from South Africa with the apartheid baggage? On the one hand, we are not 'vulnerable' selves but indeed very privileged selves. On the other hand, we are also aware of the fact that our privileged positions put us in a vulnerable situation in terms of our position as researchers on Ubuntu in an African context. We are both committed to the research and we believe that we have bona fide intentions, but historically speaking, we have no moral high ground to stand on. And therefore our involvement in this project cannot be taken for granted. It needs to be reflected on and in order to do that we took the autoethnographic route. A colloquium on Spatial Justice that was conducted in Pretoria in September 2015 was another motivation for us to explore the theme of spatial justice, as experienced by the Ubuntu researchers.

\section{The story of our involvement and preliminary reflections Sheila's story}

February 2016

I am sitting in the beautiful South African sunshine, having escaped the misery of February in England for the second meeting with the Ubuntu researchers. Trying hard to concentrate, not to be distracted by the sunshine as I write, I muse first on the many coincidences that are arising for me in my involvement in this project. I first encountered Ubuntu when I was doing my PhD,

1.The Ubuntu research project. This project is hosted at the Centre for the Advancement of Scholarship, University of Pretoria, funded by the Templeton World Charity Foundation.

Note: This article is part of the Special Collection titled 'Spatial Justice and Reconciliation', sub-edited by Stephan de Beer, of the Department of Practical Theology and the Centre for Contextual Ministry, University of Pretoria. 
which began as a narrative inquiry into the experiences and perceptions of a group of 'international' postgraduates in my School at the University of Bristol. Ubuntu - or the definition of it that I encountered at the time, 'I am because we are' spoke to me because it was oppositional to the individualist 'I think therefore I am' of Descartes and I was enjoying my encounters with any idea that appeared to contradict the concepts with which I was familiar. The process of the PhD instilled in me - or perhaps drew out from me - a delight in subverting what I perceived to be the status quo in philosophical positioning, certainly in my school and in the field of international higher education at the time. Encountering the concept of epistemological racism through the work of Stanfield $(1993,1994)$ and of Scheurich (1997) set me off on a journey of critiquing the appropriateness of the dominant paradigms in social science, in particular to inform the intercultural research in which I was engaged. These paradigms are rooted in Eurocentric philosophy yet are imposed on - and even adopted by - those from contexts with very different worldviews. It seemed to me to be wholly inappropriate to be positioning my research within paradigmatic perspectives that may have been alien to those who participated in my research. I considered it important, therefore, that, even if I were not to develop a new and more inclusive philosophy, at the very least I would write transparently about my struggles to position my research respectfully. Such critique had not been raised in the research training that I was required to undertake as a doctoral researcher. I raised it and, moreover, have been continuing to engage in similar critiques ever since, in my own research and writing, in my teaching, in particular of research methodology and in my supervision of doctoral researchers from all over the world. In doing so, I draw, in particular, on the work of those such as Tuhiwai Smith (2012), Connell (2007), Swadener and Mutua (2008) and Zeleza (2012). In the international higher education field, there were many calls in the literature for academics to be more 'reflexive' in their encounters with 'international students' but very few examples of such reflexivity. My $\mathrm{PhD}$ was intensely reflexive and all of the writing that I have done continued in a similar vein. So, my own, profound $\mathrm{PhD}$ experiences challenged me in my thinking in many ways and, subsequently, enabled me to challenge colleagues and doctoral researchers to ask similar, difficult questions of themselves.

Encountering Ubuntu was for me a completely different way of thinking about myself and the world, an important step on this doctoral journey. It was one of the many ideas or philosophies that challenged and enabled me to confrontor start to confront - my own identities as a white, British woman working in environments with people who were from former colonies and, indeed, as a woman who was often working in former colonies. I encountered ideas and concepts that I had not encountered previously, in particular with regard to philosophies of learning and teaching. As indicated earlier, these challenged me to interrogate my own beliefs and values. I had been aware, for example, of the philosophical concepts that underpinned my preferred approaches to learning and teaching but was much less aware of the extent to which they were culturally mediated. A significant outcome of the PhD experience for me was that I changed the ways in which I taught - and continue to do so - to enable a learning environment that is more congruent with the many understandings of learning and teaching brought by the students with whom I work and I hope is about more inclusive. Engaging in such dialogue with myself led to the doctorate developing strong autoethnographic dimensions, including intense reflection on my 'whiteness'.

\section{A few words about autoethnography}

Autoethnography is an approach to research that connects 'self with others, self with the social, and self with the context' (Njunjuri, Hernandez \& Chang 2010:3). Advocating autoethnography 'to further the social justice agenda', Pathak (2010:2) proposes positioning it within a postcolonial space to 'disrupt the academic imperialism of absent, omnipotent, white, male voices' (ibid., 2). It may be that I am positioned as perpetuating that 'academic imperialism' because, although not male and not feeling nor seeking to be 'omnipotent', I am white, I am from a country that was a significant coloniser of others and I work on programmes, in particular in Hong Kong, as I discuss later, that might be perceived, with some legitimacy, as academically imperialist. Soon after I began my doctorate in 2001, I started to write autoethnographically about my 'self' in my learning and teaching 'cultures'. I challenged myself to interrogate my own values, beliefs, perspectives, in particular on learning and teaching, and to expose how those beliefs informed unintended ethnocentric practices that may exclude and marginalise students. As the research progressed, more questions about my 'identities' surfaced, in particular questions about being a white, British woman, born at a particular time in history, now working with people from many different parts of the world. I have written elsewhere about my deconstruction of these identities (see, e.g. Trahar 2011) where, as I have indicated, the impetus for doing so has been driven by working in my own local context with people from different parts of the world and from diverse educational traditions. This deconstruction began with my curiosity about how students, in particular students from former colonies, felt when encountering British academics and usually, in my school, white academics, in the learning environment. My concern was that without due care and sensitivity, our UK higher education classroom could be experienced as perpetuating educational imperialism.

\section{Meandering ...}

As I am writing this now, I recall a conversation that I had a few years ago with an academic at the University of Buea in Cameroon. A colleague and I were spending a week at the university running an introductory programme on qualitative research for doctoral researchers. I had shared with him my feelings of discomfort - not at all unfamiliar - at walking into the room on the first morning and, even though I knew that this would be the case, my colleague and I being the only 
white people in the room - in fact on the campus. I shared with him my intense embarrassment at the doctoral researchers being faced, yet again, by white people in positions of authority bringing 'knowledge', in this case of qualitative research. I told him how I did as much as I possibly could right from the beginning to disabuse them of the perceptions that I assumed they were holding. What did I want from him in that conversation? Was it some reassurance that those doctoral researchers were not feeling how I assume that they were? Was it his admiration at my willingness to be open with him and to share my feelings of vulnerability? Was I looking for a pat on the back, because I was behaving so sensitively and seeking to persuade the doctoral researchers that, even though I was white, I was really OK? Was it simpler than that? Did I want him to give me his perspective? Maybe it was all of those things but in sharing my feelings with the academic at the University of Buea, he agreed with me, indicating that I was 'totally right'. That would be the doctoral researchers' perception. Here I was, 'another white woman' positioned as a lady bountiful who had chosen to share my knowledge with them. That it was up to me to change that perception, if indeed I wanted to.

\section{Coloniser and colonised}

Being part of the Ubuntu project is not the first experience I have had of working in a country that was a former colony and of all of the discomfiting emotions evoked for me in addition to my emotional responses to the complexities of post-apartheid South Africa. I have taught on the University of Bristol's two transnational programmes in Hong Kong for some 15 years. Teaching in a postcolonial context and being of a colonising country, one steps into a minefield, an environment suffused with potential difficulties. As a British academic teaching on such higher education programmes in Hong Kong, I am a 'cultural outsider'. I am an outsider in a landscape that is very familiar. Colonised by the British from 1842 until the return to China in 1997, there remain glimpses of the Empire - in street names, road signs, the double-decker buses - even, in the education system. When I began to teach in Hong Kong in 2003, I was eager to talk to people about how they felt about returning to China. Inevitably, I heard different stories from 'We are - and always will be - Chinese' to 'But the British were sympathetic colonisers'. I cannot conceive that colonisation could ever be experienced as 'sympathetic', in particular when reading Hickling-Hudson's (2011) vivid, poignant and, for me, humbling stories of her schooling in a colonised Jamaica, leading her to demand 'what would a de-colonized, de-whitened, post-colonial education system and curriculum look like?' (p. 454). Important questions for me and ones that I continue to ask of myself.

Being from a colonising nation does not, of course, make me a coloniser yet I suspect that that is often how I am positioned until I begin to speak and act and people begin to get to know me and to realise my strong commitment to the notion of 'discomfort pedagogy' (Leibowitz, Bozalek \& Rohleder 2010). Discomfort pedagogy is an invitation to students - and
I would add academics - to 'critique their deeply held assumptions'. It 'destabilises their view of themselves and their worlds' (Leibowitz et al. 2010:84). It necessitates a 'process that is painful, but contains the promise of hope for the future' (ibid). Jonathan D. Jansen 2009, writing about post-apartheid South Africa, refers, similarly, to post-conflict pedagogy, in particular, the notion of pedagogical reciprocity in which 'both sides are prepared to move toward each other' (p. 268). For me, these concepts and pedagogical practices resonate with the postcolonial concept of 'unhomeliness' (Manathunga 2007:93). Unhomeliness describes the discomfort that can be felt when we encounter values, beliefs and behaviours - new cultural practices - that appear alien to our own. Remaining with the discomfort and opening up a dialogue with the 'other' to explore why we each hold the positions that we do, creates a powerful space for new learning to occur. Such conversations, on an individual basis and with groups of people, have enabled me to strive to facilitate environments in which I can provoke discussion that can be not only uncomfortable but also illuminating and transforming. The different stories about colonisation that I hear from local Hong Kong people continue to intrigue me, making me even more determined that, in my classes, students will be encouraged to 'recognize suppressed knowledge, and to appreciate and be part of the long struggle to forge alternatives' (Hickling-Hudson 2011:463). Such behaviour reflects my belief in the importance of not being paralysed by 'our histories and cultural inheritances' (Seidler 2010:157) but in finding ways to move beyond a thoughtful understanding of them so that we develop 'ways of relating that [did] not replicate the dynamics of coloniser and colonised' (Bond \& Misfud 2006:239).

\section{The Ubuntu project}

At the time of writing, I have been involved in two meetings with the researchers in the Ubuntu project. Other academics were present at the first meeting, there because of their work with Ubuntu and their familiarity with narrative inquiry. Each researcher had been asked to send us two questions for consideration before the first meeting in Pretoria. I recall that I felt totally inadequate when faced with questions about the context but on firmer ground in responding to the methodological questions. I was transfixed by the research that those in the group were doing and humbled by some of the work being conducted with some of the most deprived people in the country. My stereotype of the white, male Afrikaner farmer was shattered as one researcher who identified as such spoke movingly about the research he was conducting with his farm manager, grappling with the ethical complexities inherent in this and how these could be addressed. I recall suggesting that many of the research topics might lend themselves to fictionalisation in the representation of the narratives, in particular where the stories were so raw and perhaps more difficult to be told. I had some anxiety about making these suggestions, worried that I would be positioned as an 'expert' for, what seemed to me, the wrong reasons. I felt that I was an outsider in so many ways. I am white, I am not South African, I am not a practical 
theologian, I have many questions about Christianity and, indeed, about any organised religion yet, in other ways I did not feel at all like an outsider. I was welcomed warmly and I began to realise that my input was valued and considered thoughtfully. At the second meeting, Julian felt it important that the researchers be encouraged to begin to be more reflexive about their methodological journey by using a chapter from my book (Trahar 2011) to frame their own reflections. I hesitated at this suggestion, wary that, once again, I might be positioned as being an expert and, in particular, as a 'white' expert from a nation whose history in the region was not exactly unblemished. Sitting in the room, hearing words that I had written being spoken by African voices and listening to how my words had stimulated people's thinking about, not only their own methodological approach but their wider journeys, I felt intense discomfort, a mixture of pleasure and embarrassment. Julian then decided that each researcher might consider fictionalising some elements of the narratives that she or he had gathered and another chapter from my book was used for this. Each person was asked to consider how she or he could use fictionalisation. Each read out the idea to the rest of us and we commented. I was stunned by the stories, by the creativity that each one was bringing but also by how each story was told so vividly that I could imagine myself, for example, sitting under the tree with the group of people that one of the researchers talked about, listening to the stories, many of them defiantly and proudly - or so it seemed to me - racist, that others in the group were told. It was on that final morning that the $\mathrm{PhD}$ itself began to be critiqued as a 'Western' academic object. I loved this conversation. Finally, it felt as if the group was ceasing to be so polite with me and with each other and really questioning critically why they had to produce a $\mathrm{PhD}$ according to a particular formula. Was this consistent with Ubuntu? What would a PhD look like?

\section{Julian's story}

My story with the Ubuntu project is one of surprise, scepticism, awareness and eventually a discovery of new meaning, and an embracement.

Although I have been involved with various projects on reconciliation and social cohesion, ${ }^{2}$ and although I have published on intercultural communication and pastoral care, I have not thought of doing a research project on Ubuntu. It came to me by surprise. One day during October 2013, I received a call from the office of the vice chancellor of the University, Prof. Cheryl de la Rey, and I was asked to come to a meeting without knowing why and what. When I arrived at her office the following day, a few other people were sitting around the table. Prof. Norman Duncan, the Dean of Humanities, and Prof. Christof Heyns, former Dean of Law and currently at the UN's desk for Human Rights, Prof. Maxi Schoeman, Head of the Department Political Sciences, and Prof. James Ogude from the Centre for the Advancement of

2.Prof. Müller is responsible for a Unit for Social Cohesion at the Centre for Contextual Ministry at the University of Pretoria and in that capacity I have been involved in the organising of two colloquia. The first was on reconciliation and social cohesion in September 2013 and the other on Spatial Justice and Reconciliation in September 2015.
Scholarship and from African literature. I felt a mixture of proud and fear to be selected by Prof. de la Rey and to form part of the initial team to work on a research proposal on Ubuntu.

We had very little time to prepare and submit the proposal to the Templeton World Charity Foundation. Each of us had to prepare a section of the proposal. My task was to make sure that the proposal was in line with the values and philosophy of the Templeton Foundation and also with the Ubuntu theology as was formulated by former Archbishop Desmond Tutu.

In a follow-up meeting, the proposal was finalised and Prof. Ogude was announced as the leader of the group. The team consisted of myself as the leader of the cluster that focusses on the spiritual and community values of Ubuntu; Prof. Maxi Schoeman with a cluster on Political Science and Prof. Christof Heyns with a focus on Law and Human Rights. The leader, Prof. Ogude would provide the philosophical and literature backbone. The project was organised in four clusters, each with a specific focus, but at the same time connected to the others and to the whole.

To our surprise and joy, the proposal was accepted by Templeton and we could start with a three-year project on 01 April 2014.

During the first few months, we as a team had a few meetings and consultations to provide structure and to help us to develop the guiding questions for the rest of the research. For me, this was a time of confusion and frustration. There were so many cliches uttered and nostalgic statements made about Ubuntu that in reaction I almost became sceptical and even cynical about our research. Fortunately, there were also the more sceptical and critical voices which resonated with my approach to research as a non-biased and open-ended venture. Prof. Tinyiko Mululeke who was a speaker at one of the colloquia, was one of the most eloquent voices in this regard. He emphasised the fact that Ubuntu is not only about being nice to each other. He emphasised the complexities of the concept in the current context of Africa where reconciliation and justice must be integrated.

Another contribution to my frustration and uncertainty was the realisation of my whiteness as a problem in this project. Strangely enough, I did not think about it at the beginning. The honour of being part of the project and being chosen to take a leading role as a theologian was overwhelming. I was also guided by my conviction that research is in any case always subjective and that the researcher is not awarded credibility by any attribute or status on his or her side but by the integrity with which the research is done. And I did not doubt my own bona fide intentions with this research. In one of the colloquia that was organised, and where I had to present and defend my research and research intentions, I was at once confronted by critique and scepticism. The questions were about Western and colonial prejudice and the 
legitimacy of a white Afrikaner male being in charge of a research project on Ubuntu. I realised then that my position and participation in this research project could not be taken for granted. At first, I was very angry that my good intentions and hard work for this project could be doubted.

After a while I realised that I had to reflect on this and that I should accept the fact that people would frown upon me as a white Afrikaner male doing research on Ubuntu. It is not an unproblematic situation. My first reaction was to defend myself and my motives. It took me a long time to reach the position where I am now, where I acknowledge my fragile and vulnerable position as a researcher, and where I realise that it is necessary to reflect on my journey with as much subjective integrity as possible.

As time went by and we became deeper and more thoroughly involved in the Ubuntu research, I became aware of changes taking place in my own understanding and attitude. I no longer experienced myself as the one trying to tell the Ubuntu story but as the one being storied by Ubuntu. I was at the same time author and reader of the research story. The experience of doing research and at the same time being read by that very research became a reality. Ubuntu was storying me while I was writing the Ubuntu story. When this dawned on me, it was like an aha-moment, a climax.

It happened one day in a different context, at what we call 'Teologiekafee' (Theology Café). Teologiekafee is a small group of open-minded theologians who meet once a month in a café to discuss relevant theological issues. On that specific afternoon in October 2015, the discussion focussed on ways we see and experience God and how we communicate with God, I had a growing sense of detachment. It was only later, when I tried to reflect on my experience, that I realised how deeply I have been influenced by the Ubuntu worldview. My whiteness, with its Western desire to analyse, systematise and order, has been so profoundly challenged and changed by my exposure to the concept of Ubuntu, that my uneasiness with theological systematisation and fragmentation grew to a deep frustration. These theological colleagues are my friends and we share the same ideas about spirituality and the ology. And yet on that afternoon I felt lost in the discussion. The only explanation I could come up with was my ongoing exposure to Ubuntu language. The idea of wholeness and the paradigm of an integrated worldview, which is so much at the core of Ubuntu-thinking has influenced me to such an extent that it strengthened my theological uneasiness with God's language and metaphors that keep God out there (an external being, the theistic God). At that stage, I had already published about and positioned myself as a panentheist. God, for me, is in everything and everything is in God. The Ubuntu philosophy is not identical with panentheism, but its understanding of reality, as an integrated whole, lies in the same direction. Ubuntu thus strengthened my panentheistic ideas and therefore my frustration with God-talk that is still, although very subtly, based on theistic metaphors and on whiteness, which asks for order and categorisation (see below the discussion of whiteness and its preference for order).

What happened on the research journey of Ubuntu, is that I have been changed. I am still the same white Afrikaner male, but my whiteness has been relativised. I was studying Ubuntu, and in the process Ubuntu was re-storying me. But that is not the end of the story, and that in itself does not give me credibility as an Ubuntu researcher. It is just part of a process in which I am being faced with my whiteness. It is part of an ongoing challenge to reflect on the meaning of being white in South Africa and working shoulder to shoulder with black colleagues on this Ubuntu research project.

\section{Facing our whiteness}

What is 'whiteness' and how is it used and understood in this article? The description given by Melissa Steyn (2005) can help us:

I believe it is best understood as an ideologically supported social positionality that has accrued to people of European descent as a consequence of the economic and political advantage gained during and subsequent to European colonial expansion. (p. 121)

This rather academic definition of Steyn's is made a bit more accessible in an interview with Richard Rohr on white privilege:

White privilege is largely hidden from our eyes if we are white. Why? Because it is structural instead of psychological, and we tend to interpret most things in personal, individual, and psychological ways. Since we do not consciously have racist attitudes or overt racist behavior, we kindly judge ourselves to be open minded, egalitarian, 'liberal', and therefore surely not racist. Because we have never been on the other side, we largely do not recognize the structural access, the trust we think we deserve, the assumption that we always belong and do not have to earn our belonging, the 'we set the tone' mood that we white folks live inside of - and take totally for granted and even naturally deserved. Only the outsider can spot all these attitudes in us. It is especially hidden in countries and all groupings where white people are the majority. (Huffington Post, 15 January 2015)

'In my opinion, "whiteness" loves order above all else (not love)', and has used the Scriptures to enforce its version of order: Christendom itself, the Crusades, the Inquisition, the genocide of the Americas, slavery, apartheid, unjust voting rights and voting privileges, the non education of woman and blacks were all justified by the Bible, and most especially by Bible thumpers!

Let's be fair here too, because when minorities are in fact the majority in a country, they tend to take on the same imposition of order, obedience, and patriarchal attitudes of control that whiteness does. The problem is always the misuse of power, and it is just that the whites have historically appropriated the most power, but I have seen every other ethnic group abuse power too.

We have quoted this long passage of Rohr because the way he explains the problem made us reflect very deeply on the 
relationship between whiteness and research. If Rohr is correct, and we believe that he is, then the preference for order comes with whiteness and through that the ability to manage. We maintain order by categorising and analysing. With our language categories we put things in place and we create control over a complex environment. The research methods and models which are a legacy of the West and therefore of whiteness are the result of the same power games.

When we then come with our whiteness (and many black academics and students have bought into the whiteness paradigm and are therefore also victims of it) to the Ubuntu research, we experience a clash of value systems and worldviews. We need to reflect upon this development and experience.

In the past two years, while involved in this research project, we have listened to many speeches and lectures on 'Ubuntu'. And when reflecting on it, it is interesting how we struggle to get a fluid and evading concept like Ubuntu under control. With definitions and all kinds of academic language categories, like 'theory', 'praxis', 'problem statement', etc., we try to organise the field and make it governable for us as white researchers. The results are not convincing. Again and again we are confronted with the paradoxes and inconsistencies of what we call 'Ubuntu'. The growing question is: Is it acceptable research practice to subject Ubuntu to whiteness with all these research methods? Should we not rather allow Ubuntu to take us on a journey and teach us in its own way?

That is why we have chosen a narrative approach where the emphasis is on listening with a deliberate not-knowing position. With this approach we have tried to open ourselves to be taken into the Ubuntu story. But still, even the narrative way of doing research is coined and created in research dominated by whiteness. The question we are reflecting on in this article is whether we have been constantly and sufficiently aware of what we are bringing into the process with our whiteness? Did we really succeed in allowing the Ubuntu story as it is, to tell and inform us? To what extent have we, with our problem statements and research questions, constructed a concept of Ubuntu, which might not exist out there? What is the ideal towards which we would like to emancipate with our research and did we reflect sufficiently on how much our ideas about better practice and the 'positive aspects' of Ubuntu were the results of our whiteness? What is the grand narrative which we have simply taken for granted and on the basis of which we are making moral and ethical judgements about Ubuntu?

Have we been open to the second part of St. Pierre's (1997:176) aim of research? According to her '... (research) aims to produce different Knowledge and to produce knowledge differently'. We were looking for 'different knowledge' about Ubuntu and we have succeeded in formulating some alternative ideas. The question is: Have we been open to the possibility of alternative knowledge production?

On the other hand, we have to consider the possibility that it is because of our exposure to the world and language of
Ubuntu, that we have been sensitised towards these questions. It is perhaps one of the most important results of our project that we have been empowered to reflect on something like whiteness and research. We have been influenced by Ubuntu on a level that we perhaps did not expect. Where we started with rather objective and distant 'research questions' about what Ubuntu is, we have now came to a place where we would like to be guided by Ubuntu in the way we do our research. This brings us to the concept of the fluidity of research identities.

\section{The fluidity of research identities}

We take the view that identity is never fixed and completed, but always emerging and fluid. We, therefore, did not only 'have' identities as a British woman and a South African man, but we are also part of a social constructionist process where, in every new context, we are becoming. New identities emerge as a result of contextual interactions. Identity changes over time in relation to the development of society (cf. Strachan 2015:11).

We need to consider the dichotomy that exists between the West and Africa, between the academic world and other communities. Perumal (2015) reminds us that:

Dichotomizing resisters and dominators ignores the complexity of resistance and ignores the multiple systems of hierarchy. It ignores the possibility that individuals can be simultaneously powerful/agentic, and powerless/oppressed within different systems. (p. 25)

Therefore, social identity should be understood as caught up in the intersecting and ever-changing dynamics of society and context.

We are reflecting on this fluid process of researcher identity formation because we do not want to be oblivious of the complexities of the intersections. Both of us carry with us a story of oppression, but we also carry with us a story of involvement. Sometimes we experience a shift in roles and we become the marginalised and we feel that our safer space for doing research is taken away from us. But it is never a linear process. Instead, it is a never-ending circular process of becoming. In this circular process, we sometimes make progress but at other times also fall again into the moulds of oppressive systems.

In her PhD thesis, Marguerite Müller (2016:43) wrote:

It is tempting to envision ourselves as being critically conscious, shaking off the oppressive baggage, and becoming triumphant agents of change. It is, however more realistic to see our involvement and contributions as an effort to build some scaffolding. We can perhaps reach political correctness, but our aim should rather be honesty in dialogue, with the danger of becoming oppressive again. But, hopefully with the possibility of being confronted and challenged again and again. (p. 43)

Finding space is an ongoing process, it is never a place of arrival. Writing this article has helped us as the authors to reflect on a journey of looking for space and in the process 
also providing space for our co-researchers. In the process of sharing and telling the story, we have been shaped and our stories became intertwined with the larger Ubuntu story. We thought we would be able to share 'results'. In the end, we can only share ourselves and our experiences. May that lead to something ...

\section{Acknowledgements}

The research for this article was made possible through a grant given by the Templeton World Charity Foundation.

\section{Competing interests}

The authors declare that they have no financial or personal relationships which may have inappropriately influenced them in writing this article.

\section{Author contributions}

Both J.M. and S.T. contributed equally to the article.

\section{References}

Bond, T. \& Mifsud, D., 2006, 'Narrative conversation between cultures: A novel approach to addressing an ethical concern', in $\mathrm{S}$. Trahar (ed.), Narrative research
on learning: Comparative and international perspectives, pp. 239-251, Symposium, Oxford.

Butler, J., 2004, Precarious lives, Verso, London.

Connell, R., 2007, Southern theory: Social science and the global dynamics of knowledge, Polity Press, Cambridge.

Hickling-Hudson, A., 2011, 'Teaching to disrupt preconceptions: Education for social justice in the imperialist aftermath', Compare 41(4), 453-465. http://dx.doi.org/1 $0.1080 / 03057925.2011 .581513$

Jansen, J.D., 2009, Knowledge in the blood: Confronting race and the apartheid past, Stanford University Press, Stanford, CA.

Leibowitz, B., Bozalek, V. \& Rohleder, P., 2010, “'Ah, but the whiteys love to talk about themselves": Discomfort as a pedagogy', Race, Ethnicity and Education 13(1), 83-100. http://dx.doi.org/10.1080/13613320903364523
Manathunga, C., 2007, 'Intercultural postgraduate supervision: Ethnographic journeys of identity and power', in D. Palfreyman \& D.L. McBride (eds.), Learning and teaching across cultures in higher education, pp. 93-113, Palgrave Macmillan, Basingstoke.

Müller, J.C., 2011, 'Postfoundational practical theology in a time of transition', HTS Hervormde Theological Studies 67(1), 5 pages. http://dx.doi.org/10.4102/hts. v67i1.837

Müller, M., 2016, 'A collaborative self-study of educators working towards antioppressive practice in higher education', PhD thesis, University of the Free State.

Njunjuri, F.W., Hernandez, K. \& Chang, H., 2010, 'Living autoethnography: Connecting life and research', Journal of Research Practice 6(1), Article E1, viewed from http://jrp.icaap.org/index.php/jrp/article/view/241/186

Pathak, A.A., 2010, 'Opening my voice, claiming my space: Theorizing the possibilities of postcolonial approaches to autoethnography', Journal of Research Practice 6(1), Article M10, viewed from http://jrp.icaap.org/index.php/jrp/article/view/231/191

Perumal, J.C., 2015, 'Critical pedagogies of place: Educators' personal and professional experiences of social (in)justice', Teaching and Teacher Education 45, 25-32. http://dx.doi.org/10.1016/j.tate.2014.09.004

Rohr, R., 2015, White privilege, Washington Post, viewed 15 May 2016, from http:// www.huffingtonpost.com/romal-tune/richard-rohr-on-white-pri_b_8985742.html

Scheurich, J.J., 1997, Research method in the postmodern, Routledge Falmer, London.

Seidler, V., 2010, Embodying identities: Culture, differences and social theory, The Policy Press, Bristol.

Stanfield, J.H., 1993, 'Epistemological considerations', in J.H. Stanfield II \& D.M. Rutledge (eds.), Race and ethnicity in research methods, pp. 16-36, Sage, Newbury Park, CA.

Stanfield, J.H., 1994, 'Ethnic modeling in qualitative research', in N.K. Denzin \& Y.S. Lincoln (eds.), The handbook of qualitative research, pp. 175-188, Sage, Thousand Oaks, CA.

Steyn, M., 2005, "White Talk": White South Africans and the Management of Diasporic Whiteness', in A.J. López (ed.), Postcolonial whiteness. A critical reader on race and empire, pp. 119-135, State University of New York Press, New York.

St. Pierre, E., 1997, 'Methodology in the fold and the irruption of transgressive data', International Journal of Qualitative Studies in Education 10, 175-189.

Strachan, J., 2015, 'Narratives of difference and sameness', Verbum et Ecclesia 36(2), 8-15. http://dx.doi.org/10.4102/ve.v36i2.1445

Swadener, B.B. \& Mutua, K., 2008, 'Decolonizing performances: Deconstructing the global postcolonial', in N.K. Denzin, Y.S. Lincoln \& L. Tuhiwai Smith (eds.), Handbook of critical and indigenous methodologies, pp. 31-43, Sage, Thousand Oaks, CA.

Trahar, S., 2011, Developing cultural capability in international higher education: A narrative inquiry, Routledge, Oxon, UK.

Tuhiwai Smith, L., 2012, Decolonizing methodologies: Research and indigenous peoples, 2nd edn., Zen Books, London.

Zeleza, P.M., 2012, 'Internationalization in higher education: Opportunities and challenges for the global south', Keynote address for Sarua Leadership Dialogue on Building the capacity of Higher Education to Enhance Regional Development Maputo, Mozambique, March 21-22, 2012, viewed 15 March 2016, from http:// www.sarua.org/files/Internationalization $\% 20$ of $\% 20$ Higher $\% 20$ Education $\% 20$ Final\%20Paper\%20-\%20Prof\%20Paul\%20Tiyambe\%20Zeleza.pdf 